\title{
Quality Assurance Indicators for School Transformation: A Paradigm Shift
}

\author{
Gertrude Theresa Uzoamaka Chiahaa, ${ }^{1, a}$, Sandra Okwundu Nane-Ejeh ${ }^{2, b}$ \\ 1'Department of Educational Foundations (Administration and Planning Unit), \\ University of Nigeria, Nsukka, Nigeria \\ ${ }^{2}$ Nigerian Educational Research and Development Council, Calabar, Nigeria \\ ${ }^{a, a, b}$ E-mail address: gtuamaka@gmail.com,gertrudechiaha@unn.edu.ng , \\ okwuly@yahoo.com
}

\begin{abstract}
The new millennium is witnessing a lot of transformational challenges in almost all realms of life including the educational system, bringing about world class standards. Consequently, education reform has become necessary in pursuance of educational quality and effectiveness. Unfortunately most educational reforms in the past decades have resulted in serious frustration and failure even though they are often based on good will. This discourse will highlight the need for transformation in education in terms of Quality Assurance (QA) indicators for quality education that is currently experiencing three waves. The different waves are based on the different paradigms and theories of education quality and school effectiveness, and they result in different strategies and approaches to education quality assurance. The first wave of school transformation focuses mainly on Internal Quality Assurance Indicators and makes effort to improve internal school performances particularly the methods and processes of teaching and learning. The second wave emphasizes Interface Quality Assurance in terms of organizational effectiveness, stakeholders' satisfaction and market competitiveness and makes effort to ensure satisfaction and accountability to the internal and external stakeholders. This paper further explained that school transformation should move towards the third wave which emphasizes strongly Future Quality Assurance Indicators in terms of relevance to the new school functions in the new century, as well as relevance to the new paradigm shift in education concerning contextualized multiple intelligences (CMI), globalization, localization and individualization. Based on the paradigm shift, a new QA indicator in terms of value added and value created indicators which are completely different are added to the list. The enhancement of value added depends heavily on improvement of internal processes while value created relies mainly on the increase in goal relevance and stakeholder satisfaction with quality of education services. Continuous institutional development becomes necessary for total QA in the secondary school system and quality management of the new secondary school curriculum that emphasises entrepreneurship education. Consequently, transformation from the traditional ways of school management, to new creative and innovative approach, such as introduction of Tripartite Curriculum for inculcating multiple intelligences, instead of mono-intelligence that is currently prevalent in the Nigerian secondary school curriculum, is therefore advocated for. so that the current paradigm shift to a new secondary school curriculum in Nigerian will surely be a success.
\end{abstract}

Keywords: education reform; transformation in education; school curriculum; school; Nigeria 


\section{INTRODUCTION}

Can quality assurance indicators actually transform secondary schools and result to a paradigm shift in school administration?

Since the beginning of the new millennium, there have been drastic shifts and social developments, brought about by rapid increases in social \& political demands; globalization, information communication technology (ICT) and consequent international market competitions. Consequently numerous educational reforms have been initiated world over including Nigeria, to tackle these challenges and enhance economic development of nations. According to Cheng (2001a) the world-wide education reforms are experiencing three waves since the 1970s. The three waves of reforms are mainly based on different paradigms and theories of educational effectiveness, and they result in the employment of different strategies and approaches of transforming schools and education. These transformations are regarded in this paper as paradigm shifts.

To become one of the 20 leading economies of the world Nigerian educational policy makers introduced a new secondary school curriculum effective from 2013 academic session this new curriculum requires that students offer a entrepreneurship education as a compulsory course. According to National Council on Examinations (NECO) all secondary schools are required to assure quality in all school activities.

\section{QUALITY ASSURANCE INDICATORS IN SECONDARY SCHOOL}

Quality Assurance is concerned with implementing the sound processes that will ultimately be used to produce quality in the education systems. It ultimately focuses on three major areas of concern, namely, input, process and output. It is used to identify potential problems in the educational process that might lead to quality products later. In institutions QA is normally implemented through two major channels, which are monitoring and supervision.

Through monitoring and supervision shortfalls in the process of education can be identified and corrected before major problems result. Potential problems in pedagogy that would affect teaching and learning are usually taken care of in the monitoring process, while supervision is concerned with improvements in teaching and learning. The highest priority of QA is to set high quality goals.

This implies that the senior management must be involved in the quality assurance processes.

Management needs to be the creator and achiever of organization's quality objectives. This is commonly the most important; most difficult and most frustrating task in QA. To have the full benefits of the paradigm shift of the new secondary school curriculum in Nigerian - this paper groups Quality Assurance Indicators into three in line with (Cheng 2000) school reforms initiatives (i) Internal Quality Assurance Indicators, (ii) Interface Quality Assurance Indicators, (iii) Future Quality Assurance Indicators.

(i) Internal Quality Assurance Indicators are concerned with signs and activities that indicate quality and improve internal school performance particularly the methods and processes of teaching and learning. Methods of lesson preparation and delivery (pedagogies) are indicators of quality. The structure shows how key internal factors such as teacher factors, curriculum factors, contextual factors, and student factors are related to student learning experiences and educational outcomes. Cheng, (1998); and Medley, (1982) observed that: 
- Student learning outcomes are the product of the interaction and relationships between the curriculum, pedagogy, student learning experiences and individual characteristics;

- Student learning experience is affected by teacher performance, pedagogy; curriculum characteristics, and classroom environment.

- Teacher performance is determined by the interaction between teacher competence, curriculum characteristics and school organizational environment;

- External teacher education, school-based teacher education, and pre-existing teacher characteristics can contribute to teacher competence; and teaching evaluation based on the information from teacher performance, student learning experience and learning outcomes can be used to facilitate development of teacher competence through staff development activities.

Teachers should therefore make use of ICT facilities in their service delivery. Also innovations and creativity should be encouraged in teachers and students. The above observations imply that, Entrepreneurship Management should replace the current dogmatic administration prevalent in Nigerian secondary schools. It is important to note that secondary school products face global competitions and so efforts should be made to ensure that teachers and school administrators have international exposure to enable them prepare the students for global competitions. Also the aim of education will include ensuring that secondary school graduates compete favourably with their counterparts globally. In other words, secondary school should clamour for world class standards.

(ii) Interface Quality Assurance Indicators involves accountability to the public and stakeholders'; expectations in terms of education quality, stakeholders' satisfaction and market competitiveness. Quality in terms of school monitoring and supervision, parental choice, parental and community involvement in governance, and performance-based funding are some typical examples of QA indicators needed to pursue and enhance effectiveness at the interface level between the schools and communities (Cheng \& Townsend, 2000). One may wonder why parents prefer private schools that charge exorbitantly over public schools that are free.

Is it possible to have free and quality education? Of course YES.-This can be made possible by school principals and teachers. Therefore efforts should be made by school administrators to satisfy stakeholders and ensure they meet attain world class standard. To ensure quality, stakeholders should participate in school administration. Groups like Mothers Association should be introduced in secondary schools. Models of school administration that can introduce quality in schools should be adopted. Some models which can be adopted by school administrators to assure quality in schools include, Legitimacy Model; Organizational Learning Model and Total Quality Management Model. These will be briefly discussed.

1. The Legitimacy Model: Since the educational environment is now very challenging, demanding and competitive, schools have to face external challenges and demands for accountability and "value for money". It is hardly possible for institutions to continue or survive without ensuring legitimacy in the community. This model assumes that in order to gain legitimacy for survival and to acquire critical resource, schools have to win support of the community, build up good public image and show evidence of accountability. Therefore, education quality mainly refers to the achievement of legitimate position or reputation in the community. Quality assurance by this model often relies on the interface activities and achievements such as building up public relations, marketing institutional strengths, ensuring institutional accountability to the 
public, and promoting institutional image, reputation and status in the community. Also, secondary schools that conform to the ethical and moral norms of the community usually gain legitimacy. Principals should therefore market their schools with good human relationships and high performance. They should open up web sites and showcase their activities and achievements. There is also need for networking with other secondary schools abroad and in Nigeria with world class standard so as to emulate them.

2. Organizational Learning Model: This model assumes that responding to changing environment such as the new curriculum; education quality becomes dynamic, involving continuous improvements and development of the members, practices, processes, and outcomes of the educational system. Studies have shown that workers in organization can be empowered to learn, be creative and innovative to provide quality services (Fullan, 1993; Senge, 1990; Schmuck and Runkel, 1985). Quality assurance in this model emphasizes the importance of organizational learning behaviours that ensure quality in education. Therefore, strategic management, development planning, and staff development are important tools indicators of quality assurance in this model. (Dempster, et al. 1993; Hargreaves \& Hopkins, 1991). The implies that for quality to be assured awareness of community needs and changes; internal process monitoring \& supervision, program evaluation, environmental analysis, professional development, and development planning need to be put in place by the school managers.

The Total Quality Management Model: Currently, Total Quality Management (TQM) is being emphasised in education. TQM is believed to be a powerful tool in enhancing quality education and increasing school effectiveness (Bradley, 1993; Cuttance 1994; Greenwood \& Gaunt, 1994; Murgatroyd \& Morgan, 1993).

The TQM model defines education quality as types of elements in the input, process, and output of schools that provide services that satisfy both the internal and external strategic constituencies completely by meeting their explicit and implicit expectations .Therefore, quality assurance by this model is mainly the total management of interface, internal people and process with outputs meeting strategic stakeholders' needs (Cheng, 1995b). This model assumes that improvement of some aspects of the management process is not sufficient enough to achieve excellence or total quality management. The critical elements of total quality management in schools include strategic stakeholder focus, continuous process improvement, and total involvement and empowerment of school members (Tenner \& Detoro 1992). Therefore, the key areas for ensuring quality include leadership, human resource management, process and information management, information analysis, strategic quality planning, internal and external customers' satisfaction, operational results, students' educational results, and school impacts on society (Fisher, 1994; George, 1992).

(iii) Assurance Indicators: Historically, several efforts have been made by the previous administration in this country to ensure qualitative education but such efforts have not yielded the expected results thereby leading to a serious need for a pragmatic paradigm shift to ensure Total Quality Management (TQM).

Due to rapid transformations in this era of globalization and information technology and knowledge-driven economy, information technology is strongly emphasized worldwide. People advocate for a paradigm shift in teaching and learning \& demand for transformation and reform in aims, content, practice, and management of education at different levels to ensure their relevance to the future (Cheng, 2000a, b; Daun, 2001; Burbules \& Torres, 2000; Stromquist \& Monkman, 2002). The future QA indicators in terms of relevance to the new secondary school 
curriculum in Nigeria should be concerned with contextualized multiple intelligences, globalization, localization and individualization. The pursuit of a new vision and aims at different levels of education, life-long learning, global networking, international outlook, and use of information and technological are just some emerging evidences of the future QA indicators (Cheng, 2001a).

The need has therefore arisen for the introduction of Tripartite Curriculum in secondary schools in Nigeria. This will enable the consideration of all students' achievements in terms of their activities; attitudes; aptitudes during their final evaluation and assessment. This implies that teaching in schools and consequent students' evaluation and assessment should be based on acquisition of multiple intelligences rather than the prevalent mono-intelligence teaching, assessment and evaluation currently prevalent in Nigerian schools. There are numerous types of intelligences and put together they are referred to as multiple intelligences. Rowe (2005) listed four intelligences as, intuitive intelligence, Innovative intelligence, Imaginative intelligence and Inspirational intelligence. He remarked that those with these intelligences also have passion for transformation and are normally willing to die for their beliefs and convictions.

Co-Intelligence Institute (2003), identified 22 intelligences thus; Practical Intelligence which they described as the ability to think in concrete examples, solve daily problems and have the tendency to survive or succeed through taking straightforward, responsive, concrete actions. This is also referred to as marketing, strategic or political intelligence -- since it deals with common sense. Verbal Intelligence according to the Institute it is the 'ability to think, communicate effectively \& creatively with words; and to recognize, use \& appreciate linguistic patterns.'

Logical Intelligence is concerned with the ability to conceptualize in abstract terms, symbols \& sequential relationships, conceptual regularities or numerical patterns, and to reach conclusions or construct things in an orderly way. This is commonly regarded as rational, analytic or mathematical intelligence. Associative Intelligence is the ability to think in nonsequential associations -- similarities, differences, resonances, meanings, relationships, etc., and to create (and appreciate) totally new patterns and meanings out of old ones. Spatial Intelligence is the ability to visualize, appreciate and think in terms of pictures and images; to graphically imagine possibilities; and to observe, understand, transform and orient oneself in visual reality.

Intuitive Intelligence also called pictorial or imaginative intelligence is the ability to know directly, to perceive and appreciate whole or hidden patterns beyond (or faster than) logic. Musical Intelligence is the capacity to perceive, appreciate, resonate with, produce and productively use rhythms, melodies, and other sounds. Aesthetic Intelligence is the ability to produce, express, communicate and appreciate in a compelling way inner, spiritual, natural and cultural realities and meanings. Body Intelligence also referred to as kinaesthetic or somatic intelligence is the ability to sense, appreciate, and utilize one's own body - movement, manual dexterity, tactile sensitivity, physical responsiveness and constraints; to create and think in terms of physiological patterns; to maintain physical health; and to relate to or meet the needs of others' bodies.

Interpersonal Intelligence is the ability to perceive, understand, think about, relate to and utilize other people's subjective states, especially, empathy and to estimate their likely behaviour.; Social Intelligence also known as team intelligence, is the ability to work with other; find identity \& meaning in social engagement; perceive, think, and deal in terms of multiperson patterns, group dynamics, needs and human communities; it includes a tendency towards cooperation and service. Affectional Intelligence is the ability to be affected by, connected to 
or resonant with people, ideas, experiences, aesthetics, or any other aspect of life; to experience one's liking or disliking of these things; and to use one's affinities in decision-making and life. Mood Intelligence is the ability to fully experience any mood as it happens (without having to judge it or do anything about it), to learn from it, and to move out of it at will -- especially to generate resilience.

Motivational Intelligence is the ability to know and to work with what moves you; to sense, think and initiate in terms of needs, wants, will, courage, responsibility and action -one's own and others. (This can include that aspect of mood intelligence that can marshal emotions in the service of a goal.) Intrapersonal Intelligence is the ability to recognize, access and deal with one's own subjective (or inner) world. (This can include aspects of affection, mood, motivational and body intelligences.) Emotional Intelligence is the ability to experience, think and deal with emotional patterns in oneself and others. (This can include aspects of interpersonal, intrapersonal, affectional, mood and motivational intelligences.) Basic Intelligence is the ability to move toward what is healthy and desirable and away from what is unhealthy or undesirable. (This can use affection and practical intelligences, or be almost automatic and instinctual.) Behavioural Pattern Intelligence is the ability to recognize, form and change one's own behavioural patterns, including compulsions, inhibitions and habits. Parameter Intelligence is the ability to create and sustain order and predictability -- to recognize, establish, sustain, and change rhythms, routines/rituals, boundaries, guiding principles/values/beliefs, etc., in one's own life. Habit Intelligence is the ability to recognize, form and change one's habits (which naturally embraces many aspects of behavioral and parameter intelligence).

Organizing Intelligence is the ability to create order in one's own life and in other lives/groups/systems. (This can include aspects of parameter, team/social, and logical intelligences) Spiritual Intelligence is the ability to sense, appreciate and think with spiritual and moral realities and patterns -- to operate from an awareness of ultimate common ground (consciousness, spirit, nature, or some other sacred dimension). (This is usually dependent on intrapersonal intelligence) and also called moral or transcendental intelligence.) Narrative Intelligence is the ability to perceive, know, think, feel, explain one's experience and influence reality through the use of stories and narrative forms (characters, history, myth, dreams, scenarios, etc.). Eco-Intelligence is the ability to recognize, appreciate, think and feel with, and utilize natural patterns and one's place in nature, and to empathize with and sustain healthy relationships with animals, plants and natural systems.

Tripartite curriculum involves three main types of intelligences which embraces all other intelligences. Obayan (2011) classified them under Cognitive Intelligence, Emotional Intelligence \& Imaginative Intelligence. He noted that the respective hard skills, soft skills and go-getting skills specific skills can be inculcated in the learners to enable them acquire the respective intelligences. Again, Obayan (2011) stressed that the inculcation of the Hard skills leads to acquisition of Cognitive intelligence while possession of Soft Skills, results to Emotional Intelligence, and Go-Getting Skills lead to acquisition of Imaginative Intelligence.

1. Cognitive Intelligence (Hard Skills) can therefore be acquired from that aspect of that curriculum that inculcates Self Expression Skills, Logical reasoning skills, Computational skills, Design / Manipulative skills and Conceptual skills in learners (Obayan 2011). This can be acquired through the new curriculum depending on the school administration.

2. Emtional Intelligence (Soft Skills) is commonly acquired through the following skills, character formation skills; inter-personal skills; life-long learning skills; Perseverance 
skills (Obayan,2011) and through the five steps of Chapman (2003), involving Selfawareness; Emotion Management, Self-motivation, Relationship Management and Emotional Coaching. Currently these skills are not normally inculcated in pupils in schools.

3. Imaginative/Creative Intelligence (Go-Getting Skills) is acquired through the inculcation of creative thinking skills, opportunity- grabbing skills, social sense/street sense skills, experimental learning skills, idea-to-product skills.

A close examination of the above skills that can be imparted through Tripartite Curriculum suggests that transformation of primary schools through the introduction of Tripartite Curriculum is a serious challenge facing administrators and planners of the secondary school system in Nigeria. Even where students acquire intellectual skills and succeed in examinations, they still remain failures in life as they have not acquired other life-saving skills, such that when they are faced with problems and challenges, they fail to cope and rather resort to unethical and immoral behaviours. Tripartite curriculum as the name implies involves multiple intelligences and is also another QA indicator which must be imbibed by the managers for secondary school transformation and success of the new secondary school curriculum in Nigeria.

\section{CONCLUSIONS}

- The QA indicators discussed in this paper can assure quality in secondary schools if actually implemented. This implies that quality assurance can lead to effectiveness of teaching, resulting to school transformation which is needed for a paradigm shift towards world class standards thereby becoming one of the 20 world best economies in the nearest future.

- The onus therefore lies on the Principals and other school administrators to ensure that the current new secondary curriculum brings about effective secondary school transformation that ushers in quality education and world class standard.

\section{Recommendations}

The paper recommends that:

- School Principals should give more time to and intensify monitoring and supervision in schools to ensure quality.

- All stakeholders should be involved in school administration to enhance participatory approach in administration.

- Tripartite Curriculum MUST be incorporated in the new secondary school curriculum for inculcating multiple intelligences in students.

- School administrators should practice TQM which emphasizes quality input, process and output as well as continued improvement in all aspects of secondary school activity including administration.

\section{References}

[1] Albrow, M. (1990). Introducton, In M.Albrow \& E. King(eds.), Globalization, knowledge and society. London: Sage.

[2] Alderfer, C. P. (1972). Existence, relatedness, and growth: Human needs in organizational settings. New York: Free Press 
[3] Beare, H., \& Slaughter, R. (1993). Education for the twenty-first century. London: Routledge.

[4] Blackledge, D., \& Hunt, B. (1985). Sociological interpretations of education. Sydney: Croom Helm.

[5] Bogan, C. E. \& English, M.J. (1994). Benchmarking for best practices. New York: McGraw-Hill.

[6] Bradley, L. H. (1993). Total quality management for schools. Lancaster, PA: Technomic.

[7] Bubb, S. (2001). Performance management: monitoring teaching in the primary school. UK: David Fulton Publishers.

[8] Burbules, N.C. \& Torres, C.A. (Eds) (2000). Globalization and education: critical perspectives. New York: Routledge.

[9] Chapman, M., (2003). The Emotional intelligence pocket book. UK.: Management Pocketbooks Ltd. www.pocketbook.co.uk

[10] Cheng, Y.C. (1995a), Function and Effectiveness of Education, (3rd ed.), Hong Kong: Wide Angle Press.

[11] Cheng, Y.C. (1995b). School Educational Quality: Conceptualization, Monitoring, \& Enhancement. In P.K. Siu \& P. Tam (eds.), Quality in Education: Insights from Different Perspectives, (pp.123-147). Hong Kong: The Hong Kong Educational Research Association.

[12] Cheng, Y.C. (1996a). School Effectiveness and School-based Improvement: A Mechanism for Development. London, UK: Falmer Press. (Korean Edition: Translated by Professor Chong-yul Park and Soon-nam Kim of Kyungpook National University, Tawgu, Korea and published by the Won-Mi Publishing Co. Korea in 2001, pages 1355; Chinese Edition: published by Taiwan Pschological Publishing Co. 2001 in press)in Developing a Framework. Eugene, OR: ERIC (Educational Resources Information Center) (no. EA 028359). Clearinghouse on Educational Management. (USA). In H. Meng, Y. Zhou, \& Y. Fang (eds.) School Based Indicators of Effectiveness: Experiences and Practices in APEC Members. (pp.197-206), China: Guangxi Normal University Press

[13] Cheng, Y.C. (1997b). A Framework of Indicators of Education Quality in Hong Kong Primary Schools: Development and Application. Eugene, OR: ERIC (Educational Resources Information Center) (no. EA 028358). Clearinghouse on Educational Management. (USA). (In H. Meng, Y. Zhou, \& Y. Fang (eds.) School Based Indicators of Effectiveness: Experiences and Practices in APEC Members. (pp.207-250), China: Guangxi Normal University Press.)

[14] Cheng Y.C., Asia-Pacific Journal of Teacher Education and Development 1(1) (1998) 116.

[15] Cheng, Y.C. (1999). Curriculum and Pedagogy in New Century: Globalization, Localization and Individualization for Multiple Intelligences. Keynote speech presented at the $5^{\text {th }}$ UNESCO-ACEID International Conference "Reforming Learning, Curriculum and Pedagoy: Innovative Visions for the New Century", 13-16 December, 1999, Thailand. 
[16] Cheng, Y.C. (2000). Globalization, Localization and Individualization for Effective Education. Keynote speech presented at the $14^{\text {th }}$ International Congress for School Effectiveness and Improvement " Global Networking for Quality Education”, 4-8 January 2000, Hong Kong.

[17] Cheng Y.C. (a)., International Journal of Educational Management 14(4) (2000) 156174.

[18] Cheng, Y.C. (2000b). Educational Change and Development in Hong Kong: Effectiveness, Quality, and Relevance, In Townsend, T \& Cheng, Y.C. (eds), Educational Change and Development in the Asia-Pacific Region: Challenges for the Future. (pp.17-56) The Netherlands: Swets and Zeitlinger Publisher.

[19] Cheng, Y.C. (2001a). Educational Relevance, Quality and Effectiveness: Paradigm Shifts. Invited keynote speech presented at the International Congress for School Effectiveness and School Improvement held in 5-9 January 2001 in Toronto, Canada, with the theme "Equity, Globalization, and Change: Education for the 21st Century".

[20] Cheng, Y.C. (2001b). New Education and New Teacher Education: A Paradigm Shift for the Future. In Cheng, Y.C., Chow, K.W., \& Tsui, K.T. (eds.). New Teacher Education for the Future: International Perspectives, (pp. 33-88). Hong Kong \& The Netherlands: Hong Kong Institute of Education \& Kluwer Academic Puhlishers

[21] Cheng, Y.C. (2001c). Towards the Third Wave of Education Reforms in Hong Kong. Keynote speech at the International Forum on Education Reforms in the Asia-Pacific Region, held in 14-16 February 2001, Hong Kong.

[22] Cheng, Y.C., Chow, K.W. \& Tsui, K.T. (eds.) (2000). School Curriculum Change and Development in Hong Kong. Hong Kong: Hong Kong Institute of Education. pp. 1-591.

[23] Cheng Y. C., Ng K. H., Primary Education 3(1) (1992) 55-64.

[24] Cheng Y.C., Tam W.M., Quality Assurance in Education 5(1) (1997) 22-31.

[25] Cheng, Y.C. \& Townsend, T. (2000). Educational Change and Development in the AsiaPacific Region: Trends and Issues, In Townsend, T \& Cheng, Y.C. (eds), Educational Change and Development in the Asia-Pacific Region: Challenges for the Future. (pp. 317-344) The Netherlands: Swets and Zeitlinger Publisher. Hong Kong Institute of Educational Research, Chinese University of Hong Kong.

[26] Co-Intelligence Institute (2003). Handbook of intelligence studies, Ed. Loch K. Johnson: USA. Routledge

[27] Cuttance, P. (1994). Monitoring educational quality through performance indicators for school practice. School Effectiveness and School Improvement, 5(2), 101-126.

[28] Daun H., Comapre 27(1) (1997) 19-41.

[29] Daun, H. (2001). Educational Restructuring in the Context of Globalization and National Policy. US: Routledge Falmer.

[30] Dempster, N. J., Sachs, G. Distant L. Logan, \& C. Tom, (1993, January). Planning in primary schools: A national study in Australian schools. Paper presented at the International Congress for School Effectiveness and Improvement, Norrkoping, Sweden. Doubleday $1990^{8}$; 
[31] Fisher, D. C. (1994). Measuring up to the Baldrige. New York: American Management Association.

[32] Fullan, M. (1993). Change forces. London: Falmer Press.

[33] George, S. (1992). The Baldrige quality system. New York: Wiley.

[34] Greenwood, M.S. \& Gaunt, H.J., (1994). Total quality management for schools. London: Cassell

[35] Hargreaves, D. H. \&. Hopkins, D., (1991). The empowered school. UK: Cassell.

[36] Medley, D. M. (1982). Teacher effectiveness. In H. E. Mitzel et al. (Eds.), Encyclopedia of educational research (5th ed., pp. 1894-1903). New York: Free Press.

[37] Murgatroyd, S. \& Morgan, C., (1993). Total quality management and the school. Buckingham, UK: Open University Press.

[38] National Examination Council (NECO) of Nigeria.

[39] Obanya, P., (2011). Educating for transformation. Keynote Address presented at the International Conference on Education at the University of Nigeria, Nsukka, 26-28 September 2011.

[40] Schmuck, R.A. \& Runkel, P.J. (1985). The handbook of organization development in schools (3rd edition). Prospect Hights, IL: Waveland Press Inc

[41] Senge, P. (1990). The fifth discipline: The art and practice of the learning organization. NY.

[42] Stromquist, N.P. \& Monkman, K. (2000). Globalization and education: integration and contestation across cultures. Lanham, Md. Rowman \& Littlefield.

[43] Tenner, A. R., \& Detoro, I. J. (1992). Total quality management. Reading, MA: Addison-Wesley. 